\title{
A THREAT ASSESSMENT OF BIOTERRORISM FROM AL-QAIDA TO ISLAMIC STATE
}

\author{
Muhammad Sheraz \\ Lecturer International Relations Department, \\ National University of Modern Languages, Islamabad \\ m.sheraz@numl.edu.pk \\ Usman Hameed \\ Associate Professor School of Law and Policy, \\ University of Management and Technology Lahore \\ usman.hameed@umt.edu.pk \\ Zarfishan Qaiser \\ Assistant Professor. University Law College, New Campus, \\ University of the Punjab, Lahore \\ zqaiser.law@pu.edu.pk
}

\begin{abstract}
The paper will focus on explaining the nature, extent and evolution of terrorism through the role of Chemical, Biological, Radiological and nuclear weapons (CBRN) such as Bio-Chemical Weapons (BCWs). It will further discuss the role of religious terrorist organizations, such as Al Qaeda and ISIS/Deash in re-defining terrorism in contemporary era by acquiring BCWs. Moreover, it will underscore the lethality and level of threat posed by BCW's when employed by the non-state actors. Additionally, it will highlight various motivating factors including political, religious, and psychological which can act as a driving force for the terrorists and non-state actors to use BCWs. Lastly, it will suggest that a change in the means and methods of terrorism predominantly comprising of BCWs as a weapon of choice for the terrorists is on the cards and it is likely remaining the feature of international politics in the days and years to come if the international treaty regime on BCWS does not adequately address the phenomenon of non-state actors.
\end{abstract}

Keywords: Terrorist Organizations, Bio-Chemical Weapons, Al Qaeda, Islamic State, Rational Actors, Biological and Toxin Weapons Convention, Chemical Weapon Convention, CBRN.

\section{INTRODUCTION}

In the late 90's, the possible acquisition and use of biochemical weapons by the terrorist organizations became a center of attention at the political level and in the media. Many terrorist groups in the recent history have tried to use weapons of mass destruction to fulfill their objectives. The idea that someday these terrorist organizations will have access to the sophisticated manifestation of these weapons has been giving sleepless nights to the policy makers. The most powerful nations of the world along with relevant international organizations have shared their serious concerns about the eventuality of such a scenario.

The 9/11 attacks on the United States (US) soil were intended to inflict maximum and indiscriminate damage, although no biochemical weapons were used but the ends were the same as today. Apart from its political implications for the world security, it also offered a seminal moment for the terrorist organizations, functioning as a benchmark for the future terrorist attacks (Kelle, 2003). Therefore, acquisitions or means of acquiring weapons of mass destruction including biochemical and nuclear weapons is something that could be on the agenda of terrorist organizations. So far, the literature on this question points out towards two possible limitations; one that the possibility of the use of such weapons is low and secondly the terrorist organizations have capacity issues in terms of infrastructure and technological knowhow (Cenciarelli, 2013). The 9/11 terrorist attacks have shown that the terrorist organizations are willing to go to any extent in order to make themselves relevant at the international level.

In the recent past, there are many examples where terrorists have used biochemical weapons to cause mass murder; the most prominent in this context was the use of siren nerve gas in Tokyo 
subway conducted by the apocalyptic "Aum Shinrikyo" sect in March 1995, which left 12 dead and over 1000 injured. Later, the use of anthrax bacterium and an attempt to blow a passenger plane by Al-Qaida targeting US nationals was another attempt by a terrorist organization to use biochemical weapons for mass murder. Most recently, according to United Nations reports, ISIS has repeatedly used biochemical weapons against civilians in Iraq and Syria between 2014 and 2016. Although, the terrorist attacks failed to achieve their objectives and were unsuccessful; however, it gave an indication of the new tactic adopted by the terrorists to carry out mass murder.

Apparently, it is not surprising keeping in view the $21 \mathrm{st}$ century terrorism related developments as majority of experts on the subject believes that religious terrorism will continue to lead the list of terrorist organizations who are most likely to use weapons of mass destruction, especially the biochemical weapons for psychological and political gains. Similarly, authors like Walter Laqueur (1999), Bruce Hoffman (1998) and Kepel (2000) agreed upon the fact that terrorism is drastically evolving in more brutish and indiscriminate way. Today, the Islamist religious terrorist groups such as Al-Qaida and ISIS/Daesh, consider that the use of CBRNs which can help further their objectives in an effortless manner. The fact that these organizations have used such (low quality) weapons in the past, to a lesser impact, this can pose a serious threat of developing or the acquisition of upgraded CBRNs. However, in this context, sophistication of WMDs like nuclear weapons and the complexity of acquiring them will push the religious organizations to go for comparatively less hard choices with great impact (Kupperman, 1989). Unlike conventional attacks using guns and bombs, a biochemical attack is a definite headline-maker news with a substantial psychological and political payoff.

Especially after the US declaration to end the 20 years long war on terror and fall of Kabul to Afghan Taliban, while it is measured as a triumph, the Islamist terrorism is losing its political significance at the international level. The desperation on part of these terrorist organizations to remain politically relevant to survive has increased their dependence on the use of the biochemical weapons. The question is whether the-biochemical weapons are becoming a weapon of choice for non-state-actors, such as the Islamist terrorist organizations, in the changing dynamics to undermine the international security using unconventional weapons?

The paper attempts to answer these questions using secondary research, more specifically qualitative research methods to identify the causal relation between the dependent and independent variables. Preferably, using arguments from different case studies to explain the causal relationship between change and adoptability by the non-state-actors to stay relevant in the fast-evolving world of the international politics.

The aim of this paper is to assess the threat of use of Biochemical Weapons (BCWs) as a weapon of choice for Islamist groups such as Al-Qaida and ISIS/ Daesh. This will be done using rational choice theory. Based on the argument that terrorist organizations being rational actors will be more focused on the ends than the means, it will assess the use of biochemical weapons by these two groups and whether to use such weapons will ensure their survivability, during these testing times when terrorism is no more a global priority.

\section{Theorizing Context}

Among much technological advancement in weaponry, biochemical weapons stand out for carrying the stigma of being illegitimate weapons, chiefly based on the fact that they are irreversible and once unleashed, can result in the total annihilation of the human living without any discrimination. However, it has not deterred state and non-state actors to develop such weapons for use or threat of use.

Rational Action Model (RAM) includes goal setting and ranking, consideration of options, assessment of consequences and profit maximization (Derek, 2012). Rational actors rank each option for its expected utility and while evaluating their success, choose the one option that produces the optimal outcome. Currently, one of the most appropriate approaches to address and explain terrorist behavior is the rational action model. A lot of researches conducted on terrorist organizations point towards a collective rationality where these organizations learn from each other and their past experiences in-order to maximize utility. Rationality theorists address to this kind of instrumental rationality, as "an instrumental relationship between ends and means" (Zwikael, 2007). This method has been effectively applied to several terror related events. Two warnings need to be kept in mind 
while using the rational actor theory in-order to explain the behavior of the terrorist organizations. First, when we try to explain any phenomena through theoretical explanation, there exists research which questions the applicability of that theory which needs to be reflected. Gregory Miller makes very valid points concerning the applicability of the rational actor theory primarily about the rationality of terrorist groups and the applicability of the theory itself. He refers to the fact that different actors in an organization may have different understandings of the concept of rationality based on their varied experiences and information. According to this understanding, any behavior can be labeled as rational since there is no such thing as absolute rationality. Secondly, no theory should be claimed as a general theory, explaining all associated behaviors. Similarly, when rational action theory is applied to explain the behavior of the terrorist organizations, it only explains part of the decision-making process involved, associated with behavior of the group. Decisions can be made at different levels of the organization by different stake holders based on the different information that they are aware of, resulting in different rational decisions. Furthermore, we know that all decisions are not rational specifically when they are made as a reaction or based on emotional priorities. These underlying concepts must be considered while assessing the applicability of the rational action theory investigating terrorist organization behavior.

\section{Historical background of CBRN's and Terrorism}

During the 1970's, the term terrorism was associated with the ethnic, nationalist, separatist and independent groups. Various organizations such as Palestine liberation organization (PL0), Irish republic army (IRA) in Northern Ireland and radical political wings in Europe like factions of red army and brigades were operating in different regions of the world. However, there were only three reported incidents of the usage of CBRNs during the 1970s (Renud, 2021).

The primary threat to international world was the rising wave of nationalism, transnational threats, drugs trafficking and crimes emanating from smaller states and non-state actors. Somehow, these issues were posing threats to the global peace and security and resulting in loss of influence by the United States in respective regions. It was a common perception that weaker states are breeding and supporting terrorist groups to have an impactful foreign policy, and use of CBRNs and WMDs can become a tool in such cases to peruse such objectives.

Al-Qaeda became potential threat for possessing CBRNs, after the 9/11, United States Department of Defense confirmed that Al-Qaida operatives were considering the option of using WMDs, especially BCWs. In 2003, another report surfaced by US intelligence which revealed that Al-Qaida may launch a cyanide attack on New York subway system (Gator, 2015). Furthermore, British intelligence report revealed that some terrorist organizations are planning to launch an attack on the EU parliament members. During the past thirty years, use of BCWs for terrorist activities and growing interest of Islamist terrorist organizations had not yet manifested fully the nature and extent of the threat, and only 26 percent out of 282 incidents involved the use of chemical weapons. However, the past incidents suggested that it was plausible to negate the threat of BCWs.

\section{Bio-Chemical Weapons (BCWs) as a Weapon of Choice}

Nuclear weapons are considered one of the most lethal and complex weapons to develop even for the most powerful and technological advanced states, which are generally plutonium or uranium-based weapons. It's almost impossible to access or to develop such sophisticated weapons for non-state actors as it requires expertise and labs, and complex processes are involved. However, the threat of developing nuclear yields and smuggling of nuclear fissile materials by a terrorist group cannot be ignored, which can be much more effective to achieve the desired objectives. Recently, smuggling of seven $\mathrm{kg}$ highly radioactive uranium in India is a vital case in point (Siddiqui, 2021).

Radiological weapons are considered dirty weapons which are comparatively easy to develop than the nuclear weapons. Similarly, Bio-Chemical weapons are simple to make and terrorist groups with limited resources can develop an extremely lethal weapon. According to Block, biological weapons are poor men's atom bomb as they provide an opportunity to the terrorist groups to take on mighty superpower like the US (Block, 2001).

It is evident that material such as anthrax, used to develop the BCWs, is accessible to the terrorist groups but the only hindrance in their way is technology. Terrorist groups are known to 
recruit skilled individuals for such purposes though development of WMDs is a time-consuming process. The usage of BCWs by terrorist groups depends upon the potential effect in terms of casualties and contamination. In any case, if they use it, the same would result in a huge loss of life and will create enormous impact in terms of achieving their target of spreading terror and insecurity. A very small quantity of BCWs is required to kill humans. But it's the methodology adopted by the terrorist groups which will gauge its efficiency and effectiveness. The BCWs characteristic of being colorless and odorless further complicates the situation for tracing the use or manufacture of such weapons.

\section{Effectiveness of BCWs}

BCWs are considered more effective when compared to conventional weapons in terms of causing damage as they can be used indiscriminately against any pre-determined target. It's their basic feature that BCWs are inherently uncontrollable, but terrorists would naturally want to use them in a targeted manner. The technique through which BCWs shall be launched also depends upon the technical characteristics and features of the weapons.

Traditionally terrorist groups are known for aiming high value targets like assassination attempts on political elites or targeting the military facilities. For attaining maximum impact, attacks are carried out in a way to avoid the collateral damages to win the domestic and international support and sympathies for the act or the cause behind it, such as freedom movement. The prime example is the assassination of former prime minister of India Rajiv Gandhi in 1991, which was caused by a female member of Liberation Tigers of Tamil Eelam (LTTE) by detonating an RDX laden belt, as a revenge for India's involvement in Sri Lanka's Civil war. Similarly, former prime minister of Pakistan Benazir Bhutto was assassinated in 2007 resulting in destabilization of the ruling government and affecting the outcome of upcoming elections in country (Edward, 1997).

Evidently, BCWs are less effective to attain the victory over the forces but it provides a tactical advantage because of its inherent ability to kill more people indiscriminately. This indicates that BCW's can be an option of tactics and strategies, but those weapons are not necessarily best for every purpose. Categorically, the technical prospects of CBRN, specifically WMD declare them the weapon of massive casualties against any civilian targets. Simultaneously, these can be used as a tool of propagation, creating such scenarios in which this weapon is considered as best defense tool against any sort of conventional attack. Furthermore, BCWs can be used to intimidate the individuals, influence public opinions for blackmailing the government, and lastly to cause the economic losses. Apparently, the conventional weapons are more productive as compared to BCWs, but terrorist have used them as a substitute to have a greater assured success since they suit their purposes. It can be argued that 21st century terrorist organizations such as Al-Qeada and ISIS/Daesh, considered the propaganda factor to have better results (Remarks by President Biden on the Way Forward in Afghanistan, 2021). However, because of technological limitations, these organizations are still not familiar with the use of BCWs.

Usually, the risk factors of failure, death or capture tend to discourage the terrorist groups. This does not; however, apply to the religious terrorists who specifically wish to attain martyrdom. Nevertheless, at times, even the Islamic terrorist organizations provide the evidence of risk aversion. For example, although Al-Qaida's flagship magazine 'inspire' encourages the use of BCWs, Daesh or other Islamist militant groups have never accepted the responsibility of having used chemical weapons in Iraq or Syria (Revill, 2017).

Consequently, dis-incentives and operational objectives could play a vital role in clarifying what sort of BCWs terrorist want to get or acquire. Furthermore, Bio-Chemical terrorism could strategically and technically evolve with the passage of time. Al-Qaida has demonstrated already that during the 1990s, they were on a mission to acquaint themselves with WMD to deter the US and Israel. Since the 9/11, Al-Qaida now operationally sees the use of WMD as a legitimate source to retribution or killings in Iraq and Afghanistan.

\section{Political Motivations and Acquisition of BCWs}

The underlying motive of any terrorist group in using CBRN's is to cause panic and disorder in the society. Commonly the reaction is restricted to their own constituency. The actors must determine various factors such as intent in using such weapons as well as to attain certain desired objectives. 
Numerous states in the world have unequivocally rejected the use of BCWs; however, their views are not as categorical regarding the use of conventional weapons. This makes sense because CBRNs are immensely lethal weapon considering the nature and indiscriminate killings they can cause along with irreversibly damaging the environment. As they do not kill a larger number of people than the conventional arms, it is probable that the use of CBRNs will be abandoned by states considering their negative impact. Furthermore, there is a possibility that the terrorist organizations may lose support for their cause, and they realize that the use of such weapons to push forward an unpopular cause may prove counterproductive.

Moreover, the linkage between such violent acts and propaganda is weak and sometimes does not prove to be effective. For instance, during the Munich Olympics 1972, nine Israeli athletes were kidnapped and taken hostage by a Palestinian group known as "Black September". The act was perceived as useless, indiscriminate, and unjustified because it did not help secure the release of Palestinian prisoners. While the incident completely failed in attaining the desired goals, yet it attracted media attention which can be considered a success to some extent in projection of terror (Meckay, n.d.).

The use of BCWs can be perceived by the inhabitants of respective constituency as a commitment symbol and it provides a way ahead to the group to work extensively to overthrow the government of those, against who they are fighting. This illustrates the involvement of secular groups in plotting the BCWs. Royal Air Force in the era of 1970's plotted five BCWs including botulinum toxin (Edward, 1997). Likewise, secular right-wing groups were also involved in plotting of BCW attacks (June, 2010). It shows that the use of BCWs was based on the conditions and circumstances rather than the strategic and technical necessities.

In contrast, religious organizations consider their constituency, in a different way, and the mobility process is also different from secular religious groups as they seem to be more intended to attack by using BCWs (Eliene, 2005). For instance, extremist right wing christens groups in the USA try to use BCWs to continue a racial war. They have two options, either to have indiscriminate way with a collateral damage or to select their respective targets very carefully to avoid the massive destruction and casualties (Huang et al., 2015). However, it can be assumed that terrorist groups using $\mathrm{BCW}$ s have varying disincentives and political motivation.

\section{Religious and Physiological Motivations}

Religious groups such as Al Qaeda and IS/Daesh play a predominant role in the current evaluation of terrorism. Since 1990s, terrorism was mainly seen driven by the theological imperatives. Now the question arises whether theological imperatives are responsible for increasing trend of indiscriminate attacks? Or are the religious motivations driving force behind use of WMDs?

The association between religious terrorism and lethality of BCWs gave birth to a perception that religiously driven terrorist groups are more actively engaged in lethal and indiscriminate tactics rather than other terror groups. Terrorism driven by theological imperatives is usually perceived as a divine duty. For instance, Al-Qaida and IS/Daesh share a common belief of colossal war. Therefore, Islamic fundamental groups evidently lie in the domain of employing theologically driven hatred and intolerance to dismantle all the maximum limits of the violence. The previous track record of the extremist right wing Christian's terrorist organization in USA manufacturing and using of BCWs weapons is mixed.

In 1983, fifteen representatives of white supremacist group Aryan Nations met at Aryan Nations Headquarters in Idaho to plot the overthrow of the federal government by resorting to tactics such as bombing and polluting the municipal water supplies of various cities (Hoffman, 2017). Moreover, the Rocky Mountain Militia of Montana was accused of attempting to recruit security guards at nuclear facility of Rocky flats (Pub1232_web.Pdf, n.d.). Likewise, Oklahoma City was targeted with bombs which resulted in 170 killings in an indiscriminate attack (Jihadists_WMDI.Pdf, n.d.). It can be concluded that religious groups are more willing and intended to arm themselves with WMD especially with more effective forms of BCWs than their secular counter parts. In religious groups, the idea of genocide killings and massacres is more continuous. In 2007, Iraq Shia community was attacked by the chlorine bombs (CAVE \& FADAM, 2007). 
In 1998, the late Al Qaeda leader Osama Bin Laden pleaded that his religious duty is to acquire WMD's and similarly, he reiterated his pledge in 2007 (Salama \& Hansell, 2005). For AlQaida, clash of civilization is an ideological concept. Analytically, theological elements of the religions can be used to provide a motivational setup for acquiring and putting to use BCWs. Likewise, when a specific group has a strong motivational force to use CBRNs, the indiscriminate attacks provide a viable option to implement its design. In a nutshell, those religious fundamental groups who opts CBRN and WMD will use religion as tool of motivation and justification for their acts.

Psychological viewpoint of individuals plays a significant role in ordering a terrorist act. Apparently, it seems impossible to determine by looking at the personalities of the terrorists that who will use CBRNs or WMD and who will not. However, such terrorists who operate under conflicting psychological motives are more likely to use CBRNs. The choice of CBRNs will be anticipated when psychological association is bonded strongly with the political, social, and tactical motives to use the CBRNs. It is not possible to identify accurately the psychological features which will determine when a certain group will be involved in the CBRN terrorism. However, at least it is clear that those authoritative groups with a psychic leader possess biggest threat of using WMD. Nevertheless, both secular and religious groups could work under psychological motivation to use CBRNs.

\section{State, CBRN Weapons and Countermeasures}

States play a vital role in global politics. One of the important components in threat accessibility of WMD and CBRN terrorism is the probability of the state sponsoring terrorism. It was the United States during the Cold War era which was blamed for equipping and supporting the Afghan Mujahedeen against communist USSR. Likewise, Soviet Union also responded in the same manner by supporting insurgent groups in Afghanistan.

The efforts to control bio-chemical terrorism culminated in coming into force of two multilateral conventions namely, the Biological and Toxin Weapons Convention (BTWC, 1972) and the Chemical Weapons Convention (CWC, 1993). Both these conventions are legally binding the parties of unlimited duration to prohibit the development, production, stockpiling and use of biochemical weapons. The obligations set forth by the two conventions are strengthened by United Nations Security Council Resolution 1540, as well as the Geneva Protocol 1925 (Refugees, n.d.). Likewise, the resolution 1540 was adopted by the Security Council unanimously in 2004. calling for non-proliferation of the weapons of mass destruction.

In South Asia, both India and Pakistan (two nuclear armed arch enemies) are signatories to BWTC and CWC. Furthermore, the two neighboring countries signed India-Pakistan agreement on chemical weapons 1992. The agreement provided for complete prohibition on chemical weapons. It further contained an undertaking not to possess, develop, stockpile, use or assist in the production of these weapons (India Pakistan Agreement on Chemical Weapons, n.d.).

However, the effectiveness of these international conventions and bilateral agreements is marred by the absence of any verification mechanism or any international body to monitor the compliance. In addition, national implementing legislation has been inconsistent. As a result, number of states have been charged with allegations of acquiring and stockpiling these weapons (Dunworth, 2006). For example, in 2017, Russia was accused by the US to be involved in production and development of these weapons. Similarly, in the aftermath of 9/11, the US expressed concerns about Libya, Syria, Iraq and North Korea of developing and producing bio- chemical weapons (The Biological Weapons Convention (BWC) At A Glance|Arms Control Association, n.d.). On the other hand, the international community was stunned when $6 \mathrm{~kg}$ of radioactive material was recovered by Indian police from Indian nationals in the eastern state of Jharkhand (India Arrests Alleged Uranium Traders | Arms Control Association, n.d.).

In 21st century, several events can be referred in which states were alleged of sponsoring and using CBRN and WMD. United States after 9/11 redefined its national security policy under the premise of states sponsored terrorism. There was no solid evidence of involvement of any state in the terrorist act of 9/11, but overwhelming evidence related to the proliferation of WMD was sufficient to cause drastic shift in US foreign policy against the use of CBRNs.

The prime indication of states sponsored terrorism hinted by United States after declaring some states "axis of evil" which includes Iraq, Iran, and North Korea (Bush Labels North Korea, Iran, 
Iraq an 'Axis of Evil' | Arms Control Association, n.d.). These states were found involved in sponsoring and arming the non-State actors globally, jeopardizing the peace and security in the world. The international peace committee agreed to the fact that rogue states were behind arming and sponsoring terrorism. These misconceptions among states about each other's resolve to disband biochemical weapons can be addressed only by establishing strong international monitoring regimes to verify compliance with the convention obligations, including the adoption of domestic enabling legislation.

\section{Covid-19 and Related Vulnerabilities}

Since 2019, Covid-19 has taken the world by surprise as it spread through international trade and travel, resulting in millions of deaths and billions of dollars' worth economic losses to the global economy. While Covid-19 started from China, the origin of the pandemic is disputed, till date. Evidently, there are misgivings among states about each other's commitment of not to acquire biochemical weapons. For example, it is said that China has mishandled coronavirus pandemic and the disease could have emerged from Wuhan Institute of Virology. Nonetheless, the intelligence reports of the United States do not support this theory and provide no definitive answers to the question of origin of Covid-19 (New U.S. Intelligence Report Doesn't Provide Definitive Conclusion on Covid-19 Origins - WSJ, n.d.). The possibility of a weaponized use of the pandemic has been dismissed in the recent reports by the Western intelligence agencies (Coronavirus Origins: US Intelligence Report 'inconclusive' - BBC News, n.d.).

Pandemics like bio-attacks are unconventional in nature with widespread and indiscriminate effects, although Covid-19 is not an episode of weaponized use of bio-agents for political objectives, it has underlined the potential of threat or use of such weapons by terrorist organizations to maximum impact ('The Havoc Wrought by Covid-19 Will Spark New Concern over Bio-Weapons', 2020).

As many experts and scholars including Andrew Silke have expressed concerns that the continuing devastation of Covid-19 may lead to a resurge among the terrorist organizations (Dass, 2021) such as Al-Qaeda and IS to acquire bio-weapons for indiscriminate use in the near future.

Bioterrorism may not pose an imminent threat; however, the existing countermeasures and the events unfolding in the wake of Covid-19 pandemic has shown a lack of preparedness on part of the global community to face such an eventuality.

\section{CONCLUSION}

BCWs can be considered as one of the most significant threats to the peace and security of contemporary world. It is believed that in future, there might be an increase in the use of BCWs or WMD. But there will be a difference in the imperatives of developing and using of these weapons amongst different groups. Consequently, the nature extent of the threat of BCWs shall be irregular and erratic because motivation varies amongst different terrorist groups.

Realistically, organized terrorist groups will try to access and acquaint themselves with BCWs more as compared to disorganized ethnic or cultural groups. Eventually, the drive of using BCWs is more among the politico-religious groups, and these have recorded drastic increase since the late 90 's. It can be assumed that in the future, there would be a huge threat of the use of such weapons. Mostly, these threats will be expected to be an outcome of the uprising of a particular strategic, political, and religious group with the combination of an idiosyncratic behavior of a terrorist organization. Who will be willing to use such mass extinction weapons? Arguably, in this context, two organizations Al Qaeda and IS will pose the most significant threat for two obvious reasons. First, they want to remain relevant at the global level in-order to survive and consequently, the prospect of losing will make them more risk acceptant in the process. Secondly because they are involved in a vicious competition to outlive each other which can be achieved through acquisition of most sophisticated means to justify their ends.

In brief, BCWs can be declared as low probability weapons with high consequence of threat. Now the current scenario of global terrorism is extremely lethal and unpredictable, Covid-19 has added further complexity to this phenomenon which seems more sustainable now. The gulf crises, Arab spring, Syrian refugees' crises, ethnic conflicts in Africa, terrorism in Pakistan, Afghanistan and fall of Kabul has further enhanced the role of BCWs and weapons of mass destruction. 
International peace apparently seems to be a vague and blur term. The states are involved in a complicated race of attainment of subjected goals through breeding, sponsoring, and providing the safe havens to the non-state actors. BCWs because of their capacity to inflict greater damage at low cost and simplified technology, automatically become weapon of choice for these non-state actors.

The international community has banned the use of BCWs by signing 1972 convention on prohibition against biological weapons and 1993 chemical weapons convention, and because of this, an individual using such weapons can be held internationally and domestically responsible for war crimes. However, as the terrorist groups and non-state actors quite often operate independent of state control, they are not deterred by the enforcement mechanism of the treaties. Moreover, a religious terrorist or a suicide bomber cannot be discouraged by the fear of consequences. Hence, non-state actors and terrorist groups remain the two entities most likely to employ BCWs to accomplish their objectives.

\section{REFERENCES}

Al Qaeda's Pursuit of Weapons of Mass Destruction - Foreign Policy'. Retrieved from; https://foreignpolicy.com/2010/01/25/al-qaedas-pursuit-of-weapons-of-mass-destruction/.

Augenbraun, Eliene. Weapon of Mass Attraction. (2005). Nature. 357-58. Baby Gator." The Independent Florida Alligator. (23 December, 2015). Retrieved from; http://www.alligator.org/news/photo/image 3f119d8c-e978-11e0-8a74-001cc4c03286.

Baram, A. (n.d). Religious Extremism and Ecumenical Tendencies in Modern Iraqi Shi'ism. The Sunna and Shi'a in History.

Beach, D. (2012). "Understanding the Choice Situation". In "Analyzing Foreign Policy", Beach, D. (2012). Palgrave Macmillan.

Benazir Bhutto Assassination: "Most Wanted" in Murder Resurfaces. (26 June, 2018). BBC News, https://www.bbc.com/news/world-south-asia-44607844.

Block, S. M. (2001). The Growing Threat of Biological Weapons. 11.

Bush Labels North Korea, Iran, Iraq an 'Axis of Evil' | Arms Control Association. (n.d). Retrieved from; https://www.armscontrol.org/act/2002-03/press-releases/bush-labels-north-korea-iraniraq-axis-evil

Calahan, A.B. (2021). Countering Terrorism: The Israeli Response to the 1972 Munich Olympic Massacre And The Development Of Independent Covert Action Teams. Retrieved from; https://fas.org/irp/eprint/calahan.htm.

Christopher, D. (2009). Terrorist Groups and Weapons of Mass Destruction: Risk Assessment and Counterstrategies. Nomos Verlagsgesellschaft mbH \& Co. KG.

Coronavirus origins: US intelligence report 'inconclusive'. (n.d). BBC. Retrieved from; https://www.bbc.com/news/world-us-canada-58329980

Crenshaw, M. (1998). The Logic of Terrorism: Terrorist Behavior as a Product of Strategic Choice, In Walter Reich (Ed.). Origins of Terrorism. Woodrow Wilson Center Press,

Dass, R. A. S. (2021). Bioterrorism: Lessons from the COVID-19 Pandemic. Counter Terrorist Trends and Analyses, 13(2), 16-23.

Dunworth, T. (2006). National Implementation of the Biological Weapons Convention. Journal of Conflict and Security Law, 11(1), 93-118.

Eitzen, E. M. (1997). Use of biological weapons. Medical aspects of chemical and biological warfare 437-450.

Hoffman, B. (2017). Inside Terrorism. Columbia university Press

India's Nuclear Recklessness - Part I. (2021). Retrieved from; https://www.thenews.com.pk/print/847337-india-s-nuclear-recklessness-part-i.

Kelle, Alexander, \& Schaper. A. (2003). Terrorism using biological and nuclear weapons: a critical analysis of risks after 11 September 2001.

Kupperman, R. \& Kamen, J. (1989). Final Warning: Averting Disaster in the New Age of Terrorism. Doubleday.

M Commons Statement: Intelligence and Security Committee Report on Fusilier Lee Rigby." States News Service. (2014). Retrieved from; http://www.highbeam.com/doc/1G1-391425930.html?

Miller, G. (2013). Terrorist Decision Making and the Deterrence Problem. Studies in Conflict and Terrorism, 36,132-151 
PM Commons Statement: Intelligence and Security Committee Report on Fusilier Lee Rigby." States News Service. (2014). Retrieved from; http://www.highbeam.com/doc/1G1-391425930.html?

Remarks by President Biden on the Way Forward in Afghanistan. The White House. (14 April 2021). Retrieved from; https://www.whitehouse.gov/briefing-room/speechesremarks/2021/04/14/remarks-by-president-biden-on-the-way-forward-in-afghanistan/.

Renaud, Pr FNR. 'NRBCe: Terrorist Chemical Weapons Attacks'. Ouvry - CBRN Protective System. (2021). Retrieved from; https://www.ouvry.com/en/nrbce-terrorist-chemical-weaponsattacks/.

Revill, J. (2017). "Past as Prologue? The Risk of Adoption of Chemical and Biological Weapons by Non-State Actors in the EU" 4. European Journal of Risk Regulation, 63, 626-642

Ricin Suspects Linked to al Qaeda. (16 January, 2003). CNN.

Rise of the Heretic. (2015). Mails Today. Retrieved from; http://www.highbeam.com/doc/1G1427182804.html

Salama, Sammy, \& Hansell, L. (2005). Does intent equal capability? Al-Qaeda and weapons of mass destruction. Non-proliferation Review, 12(3), 615-653.

Scores Killed in Iraq Chlorine Bomb. (2 July, 2021). Aljazeera. Retrieved from; https://www.aljazeera.com/news/2007/5/16/scores-killed-in-iraq-chlorine-bomb.

Significant Terrorist Incidents, 1961-2003: A Brief Chronology. (2 July, 2021). Retrieved from; https://fas.org/irp/threat/terror_chron.html.

The havoc wrought by covid-19 will spark new concern over bio-weapons. (2020, April 23). The Economist.

The National. (n.d). UN: ISIS Used Chemical and Biological Weapons against Iraqis. Retrieved from; https://www.thenationalnews.com/mena/iraq/un-isis-used-chemical-and-biological-weaponsagainst-iraqis-1.1218090.

The White House. Remarks by President Biden on the Way Forward in Afghanistan. (2021). Retrieved from; https://www.whitehouse.gov/briefing-room/speechesremarks/2021/04/14/remarks-by-president-biden-on-the-way-forward-in-afghanistan/.

UN: ISIS Used Chemical and Biological Weapons against Iraqis. (2 July, 2021). The National. Retrieved from; https://www.thenationalnews.com/mena/iraq/un-isis-used-chemical-andbiological-weapons-against-iraqis-1.1218090.

War in His Hands; Exclusive Irish Baffin Will Decide If Saddam Has Hidden Weapons. (2021). The Mirror. Retrieved from; http://www.highbeam.com/doc/1G1-98072868.html

Zwikael, O. (2007). Al-Qaeda's Operations: Project Management Analysis. Studies in Conflict and Terrorism, 30, 273-274 